\title{
THE PRIEST, THE PSYCHIATRIST AND THE PROBLEM OF EVIL
}

\author{
PUNITA MiRANDA
}

PHANÊS • VOLUME $2 \cdot 2019 \bullet P P .104-143$

https://doi.org/10.32724/phanes.2019.Miranda 


\begin{abstract}
This paper clusters around the problem of evil within the framework of depth psychology. The first part briefly introduces the narrative of the Book of Job as an example to contextualise how the ultimate question of God's relation to evil remained unanswered and was left open-ended in Christian theology. The second part offers a historical reconstruction of the unresolved polemic over the nature of evil between Carl Jung and the English Dominican scholar and theologian Victor White (1902-1960). It explores their different speculations and formulations concerning evil and its psychological implications, until their final fall-out following White's harshly critical review of Jung's most controversial work on religion, Answer to Job. The final section of this paper introduces further reflections on a challenging theme that is no less resonant and relevant in today's world of terrorism in the name of religion than it was in a post-war Europe struggling to recover from totalitarianism and genocide.
\end{abstract}

\title{
KEYWORDS
}

Carl Jung, Victor White, Book of Job, Answer to Job, evil. 
God has turned me over to the ungodly and thrown me into the clutches of the wicked.

All was well with me, but he shattered me; he seized me by the neck and crushed me. He has made me his target;

his archers surround me.

Without pity, he pierces my kidneys and spills my gall on the ground.

Again and again he bursts upon me; he rushes at me like a warrior.

I have sewed sackcloth over my skin and buried my brow in the dust.

My face is red with weeping, dark shadows ring my eyes;

yet my hands have been free of violence and my prayer is pure. (Job 16:11-17).

he Book of Job (600-300 B.C.) is part of the 'Wisdom'
books in the Judeo-Christian Bible and has been
universally admired as a 'literary masterpiece' of 'the
highest magnitude' of poetic dialogues and narrative prose (Bishop 2002:3, Parsons 1981:213). Its composition most likely took place in the $5^{\text {th }}$ century between the Babylonian holocaust and through the period of exile (587-538 BCE). The book is divided in five parts: a) the prologue on earth and in heaven; b) the symposium-dialogues between Job and his three friends; c) three monologues: poem to wisdom, Job's 
closing monologue, the speeches of Elihu; d) dialog with God; e) epilogue (Chase 2013:5). The figure of Job, in Jewish and non-Jewish contexts, has inspired many philosophers, religious thinkers, and intellectuals, as well as capturing the imagination of painters and musicians. ${ }^{1}$ Job's exemplary virtue, with its ongoing variations in interpretation, from around the $6^{\text {th }}$ century, has become a timeless model for contemplating the inscrutability of Divine Providence.

The Book of Job is a tragic story of suffering, misfortune and endurance. The righteous and faithful Job becomes a victim of a wager made between Yahweh and Satan (Job 1:6-12). During this trial Satan challenges Job's piety and God allows Satan to afflict Job with severe physical pain, emotional loss and grief (Job 1:13-20; 2:7). Job sees no justice in his sufferings and yet tries to understand why he is being punished, since he has not sinned. Three friends, Elipahz, Bildad and Zophar, first come to comfort Job (Job 2: 11) but then they argue that Yahweh is beyond human understanding (Job 22) and perhaps Job is suffering from a 'hidden sin' (Job 4:7-21; 11:7; 15; 18) (Parsons 1981:144). Once again Job protests his guiltlessness (Job 6:24-30; 7:11; 10:2). In the face of God's silence and absence (Job 23) Job is aroused by anger and through his bitter complaints and endless torment (Job 16, 19), he disputes his innocence (Job 31), arguing his case 'before God against a God' (Job 13:3) who is indifferent to his plight (Job 27). In his revolt against God, Job hopes for vindication (Job $13: 18 ; 31 ; 35$ ) and demands to know where wisdom is to be found (Job 28). God ignores his plea (Job 30:20; 31:35). The only answer that Job receives is through the angry remarks of another friend, Elihu (Job 3237), and through God's appearance out of a whirlwind, showing aspects of His creation from stars to animals, including monsters like Behemoth and Leviathan (Job 38-41). After contemplating the cosmos Job repents and surrenders to the supremacy of God (Job 42:1-6). Yahweh then rewards him for his faithfulness and endurance; Job's suffering is removed and his restoration includes health, twice as much property as before, new children, and an extremely long life (Job 42:7-17).

The Book of Job still provides a lifetime reflection on how a good God could produce evil deeds; furthermore, it portrays in a very individual way the nature of human suffering and addresses profound questions

\footnotetext{
${ }^{1}$ For a comprehensive list of commentaries on the Book of Job, see Bishop (2002:4-14). For visual and musical examples see especially the nineteen watercolours illustrations and the twenty-two engravings of William Blake (1757-1827) of the Book of Job; Marc Chagall's (1887-1985) two lithographs 'Job Praying' and 'Job in Despair', a tapestry called 'Job' dedicated to all the disabled in the world; and Vaughan Williams' (18721958) piece, Job: A Masque for Dancing.
} 
concerning rewards and punishments, the relationship between suffering and $\sin$, faith and hope. Job as the innocent sufferer, on the one hand had to submissively endure a test of his sincerity, but on the other hand, as a rebel, he directly addressed God, questioning His unjust punishments. In this manner Job's plight epitomised the undeserved suffering of mankind; his echoing cry challenging the divine-human relationship has never lost its vitality. It is this aspect of Job's audacity that Jung further elaborated in his book Answer to Job. ${ }^{2}$ Jung believed that Job's story and his questioning of God foreshadowed modern existential questions about a highly debatable all-good God who never gave an adequate answer to either the problem of evil, or His complicity in its origin and presence in the world.

The opposites of good and evil, psychologically speaking, correspond to positive and negative aspects of human nature. The question of destructive forces manifesting within individuals and as a group phenomenon has recently been discussed in two collections of essays: Ethics of Evil: Psychoanalytic Investigations and Humanizing Evil: Psychoanalytic, Philosophical and Clinical Perspectives, both edited by the psychoanalysts Ronald C. Naso and Jon Mills in 2016. They explore the controversies surrounding definitions of evil, the plurality of its manifestation in the world and the intrinsic link between human freedom and the potential for evil. In sharp contrast to the integrative depth-psychological approach of evil discussed in these collections, this paper reconsiders the compelling narrative of Yahweh-Job in which Jung moves from metaphorical considerations of God and evil to questions of collective responsibility. Jung declares that we are all not only capable of committing individual crimes, but are also collectively responsible for the destructive actions of mankind. A case in point, that will be discussed later, is his perspective on 'the dark God [who] has slipped the atom bomb and chemical weapons into [man's] hands and given him the power to empty out the apocalyptic vials of wrath on his fellow creatures' (Jung 1952, ATJ, CW11:§747). For Jung, the possibility of universal destruction through the atomic bomb had granted man an 'almost godlike power',

\footnotetext{
${ }^{2}$ Antwort auf Hiob was first published in 1952 in Zürich. Then it was privately translated to English as Answer to Job by the Jewish analyst Dr. James Kirsch for a seminar held in Los Angeles in 1952-53 to a limited number of training analysts. In 1953 for the second edition of Answer to Job, Jung incorporated the corrections suggested by Kirsh. The current translation done by R.F.C. Hull was first published in London in 1954 and reprinted in 1956 by the Pastoral Psychology Book Club in New York. The book is now part of The Collected Works of C. G. Jung: Psychology and Religion West and East volume 11 printed in 1958. For more see Jung Letters, vol. 2:104; Jung, CW11:vii; Lammers (2007a:254, n5).
} 
but the question arises, do we have the moral maturity to handle such responsibility?

\title{
ANSWER TO EVIL
}

\begin{abstract}
Naturally we can believe that God is different from the image of him that we possess, but it must be admitted on the other side that the Lord himself, while insisting on the Father's perfect goodness, has given a picture of him which fits in badly with the idea of a perfectly moral being. (A father who temps his children, who did not prevent the error of the immediate parousia, who is so full wrath that the blood of his only son is necessary to appease him, who left the crucified one to despair, who proposes to devastate his own creation and slay the millions of mankind to save very few of them, and who before the end of the world is going to replace his Son's covenant by another gospel and complement the love by the fear of God.) It is interesting, or rather tragic, that God undergoes a complete relapse in the last book of the New Testament (Jung to Père Lachat, 27 March 1954, CW18:§1556).
\end{abstract}

Through his Christian upbringing, Jung had a long-standing engagement with the question of evil and its problem plays an important role in his depth psychology, being this particularly concerned with what is lurking beneath the surface of consciousness. Jung used the term 'shadow' to describe the hidden, dark and inferior parts of the personality. These contents, drives or impulses can be experienced as 'bad' or 'evil' and are thus repressed and split off due to their conflicting and incompatible nature with the personal values or/and collective moral codes. Jung believed that Christianity repressed the animal instinct and neglected the task of dealing with evil especially by its 'tremendous compulsion towards goodness' (Jung CW10:§20). His psychology offers a possibility of assimilation and transformation of evil by a process of psychologically integrating the compensatory significance of what lies in the shadow. ${ }^{3}$ Jung read the

\footnotetext{
${ }^{3}$ On Jung's individual and collective shadow see Jung, The Archetypes and the Collective Unconscious, (1934/1954, CW9i:§\$1-86); Aion: Researches into the Phenomenology of the Self, (1951, CW9ii:§§13-19); 'The Role of the Unconscious' (1918, CW10:§§1-48); 'After the Catastrophe' (1945, CW10:§§400-443); 'The Fight with the Shadow' (1946, CW10:§§444-457). On Jung on conscience and ethical behaviour, see 'A Psychological View of Conscience' (1958, CW10:§§825-857) and 'Good and Evil in Analytical Psychology’ (1959, CW10:§§858-886).
} 
Book of Job for the first time when he was still a child and with a shock discovered Yahweh to be unjust, an evildoer with no consideration for human suffering (Jung, in McGuire 1977:225-234). In his 'autobiography', Jung recounts that if he had heard how 'the overpowering God can work His terrifying will on helpless human beings' it might have 'opened his eyes' to understand the question whether was God or the devil who confronted him with his dream of the man-eating phallus (between the ages of 3 and 4) and with a vision of God (age 12) destroying His own church by defecating on the roof of Basle Cathedral and shattering it (Jung, MDR:64; 26-28; 52-56). ${ }^{4}$ By the age of sixteen he was already 'gravely doubting God's goodness', especially due to the fact that $\mathrm{He}$ Himself planted in Eden, 'that poisonous serpent, the devil', spoiling the glory of paradise. Jung finally discovered in Goethe's Faust a confirmation of his feelings regarding the powerful sense of the reality of evil:

Here at last is someone who takes the devil seriously and even concludes a blood pact with him-with the adversary who has the power to frustrate God's plan to make a perfect world (Jung, MDR:76-77).

Even though the narratives of Faust and Job are vastly different, their parallel is important because both are based on the same premise of a bargain being made with Satan. John Williams, one of the translators of Goethe's Faust pointed out that Goethe used the 'model laid down in the Book of Job (1:6-12) to suggest the possibility of Faust's damnation' (Williams 2007: xv). Jung also observed that 'Faust is introduced like Job' (Jung 1949, 'Faust and Alchemy', CW18:\$1694). ${ }^{5}$ As a psychiatrist, Jung was not only concerned with the effect of evil in individual life and society, but also with the part it played in religion. His mature writings often criticised the naïve assumptions of the Christian doctrine of evil, ${ }^{6}$ along with his considerations on 'the pending answer to the Gnostic

${ }^{4}$ I am citing Jung's Memories, Dreams, Reflections (hereafter MDR) aware of Shamadasani's article 'Memories, Dreams, Omissions' (Shamdasani 1995), where he clarifies that Jung's MDR should be read as a 'biography' instead of an 'autobiography'.

${ }^{5}$ For more, see Edinger (1992b:88); Stein (2007:313).

6 Jung's first public polemic against the Catholic treatment of evil as a privation of good might have been his lecture 'Zur Psychologie der Trinitätsidee' at Eranos in 1940 ex tempore, the version printed in Eranos Jahrbuch 1947 had been reconstructed from the notes of his listeners. In 1947 he revised and expanded it for republication, now part of Psychology and Religion: West and East (CW11: $\$ 169-295)$. Also cited in Lammers (2005:20, 79 n51). 
question as to the origin of evil' (Jung MDR:350), emphasising how the 'lack of insight deprives us to deal with it' (Jung CW10:§572). Jung was very interested in the thought of early Christian Gnostic writers who recognised the equality of good and evil:

\begin{abstract}
The dualism of the Gnostic systems make sense, because they at least try to do justice to the real meaning of evil. They have also done us the supreme service of having gone very thoroughly into the question where evil comes from ... in a monotheistic religion everything that goes against God can only be traced back to God himself (Jung 1942/1948, CW11:§249).
\end{abstract}

Jung's initial encounter with the Gnostic tradition was in 1911 while working on Transformations and Symbols of the Libido (1911-1912) and he discussed Gnosticism throughout his writings. In 1952 the Institute in Zürich purchased one of the Gnostic manuscripts recently discovered at Nag Hammadi and it was named the 'Jung Codex' in honour of Jung's significant research and engagement with Gnosticism. Shamdasani pointed out that the Red and Black Books made evident that Jung was searching for historical parallels to his own experiences in Gnostic writers when he further engaged with them during his military service in January and October 1915. In 1916 Jung wrote Seven Sermons to the Dead (Septem Sermones ad Mortuos), a 'psychotheological' cosmology similar to an ancient Gnostic myth. In Memories Jung later clarified: 'Between 1918 and 1926 I had seriously studied the Gnostics, for they too had been confronted with the primal world of the unconscious' (Jung MDR:226). For Jung the Gnostics were credited with having found suitable symbolic expressions of the self, of the conflict of the opposites and in the Abraxas figure he saw a representation of the union of the Christian God with Satan (Shamdasani 2009: 205-6). Jung's open and public interest in Gnosticism has generated debate, commentaries and several misunderstandings. ${ }^{7}$

Jewish philosopher Martin Buber (1878-1965) accused Jung's psychology of being a revival of Gnosticism and they were in a controversy after the publication of Answer to Job (Buber 1952:63-93, 131-139;

${ }^{7}$ For a comprehensive list of scholars who have written about Jung's Seven Sermons and his connection to Gnosticism prior to the publication of the Red Book, see: Shamdasani (2009:346, n. 81). For commentaries post publication of the Red Book see especially: Maillard (2017; 2011:99-116; 2014:81-93); Owens (2010); Drob (2012:201-257). See also Ribi (2013:1-33), where Owens complements the earlier German edition, providing in his foreword a lengthy discussion of the Red Book and Jung's initial encounter with the Gnostic tradition. 
Jung 1952, CW18: $§ 1499-1513) .{ }^{8}$ For Jung, evil is a force in its own right and argued that the Church doctrine of privatio boni, where evil is merely the absence of good is a 'desperate attempt to save Christian faith from dualism' (Jung 1958, CW18:\$1593) and further formulated it as a challenging metaphysical dilemma: 'either there is a dualism and God's omnipotence is halved, or the opposites are contained in the monotheistic God-image.' (Jung 1958, CW10:§844). This topic shall be explored in the next part of this paper, since it was precisely the impasse over the nature of evil that was the main feature of Jung's enduring debate with Victor White that culminated in Answer to Job.

Jung did not take either the relationship of evil to God or the negligence of man's potential for being an instrument of evil, lightly. His engagement with the matter was set very much against the background of the world in which he lived - from the outbreak of World War I, when he came to the conclusion that his disturbing prewar visions had been prophetic, to the 'catastrophic epoch' of World War II, which saw 'unprecedented fury of destruction' (Jung 1916, 'Preface to the First Edition' of 'On the Psychology of the Unconscious', CW7:§§1-201), until the period preceding the end of his life in 1961, dominated by the economic ideological tensions and nuclear escalation of the Cold War, Jung was busy writing essays concerned with the meaning of apocalyptic events (Jung 1945/1946, CW10:§§371-487). He not only spoke about the mental condition of the West, addressing the pathological split in man that tended to 'make his neighbour responsible for his own evil qualities' (Jung 1916, 'Preface to the First Edition' of 'On the Psychology of the Unconscious'), but also psychologically examined the metaphysical Christian view on evil that 'exonerated man's conscience of too heavy a responsibility.' (Jung 1956/1957, CW10:§573). In a letter to Victor White in 1949 he spoke forthrightly and to the point:

As long as Evil is "non-being", nobody will take his own shadow seriously. Hitler and Stalin go on representing a mere "accidental lack of perfection". The future of mankind very much depends upon the recognition of the shadow. Evil is - psychologically speaking—terribly real' (Jung, in Lammers 2007a:143).

\footnotetext{
${ }^{8}$ For a comprehensive account of the dialogue between Jungian and Gnostic studies, see Ribi (2013).

9 Jung was on active duty during WWI. His duties were: 1914, 14 days; 1915, 67 days; 1916, 34 days; 1917, 117 days. Cited in Shamdasani (2009:201).
} 
Jung used biblical symbols as keys to interpret psychological agents in the human psyche, he believed that the possibility of universal destruction through the atomic bomb had granted man an 'almost godlike power' (Jung 1959, CW10:§879; also Jung 1952, ATJ, CW 11:§747) and that the consequences for having so much power over nature burdened him with a 'high degree of ethical responsibility.' (Jung 1946, CW10:\$451). He was of the opinion that human beings could no longer afford to deny their fair share in evil deeds; that is to say, it is part of the human task to recognise that even the darkest shadow represents an aspect of each single one of us. The idea of evil being contained within God was anticipated in the chapters 'Hell' and 'The Sacrificial Murder' of Jung's Red Book. There Jung realised that as human beings we are all not only capable of committing crimes, but also, responsible for their collective deeds. Jung used the analogy of the famous quote by the Roman playwright Terence (c.186-159 BC) that appeared in Heauton Timorumenos: 'nothing of that which is human is alien to me' to illustrate this idea. He even believed that it was his duty as a medical psychologist to be able to understand it (Jung 2009, RB:290, n149). Jung later elaborated this as an 'unsatisfied criminal instinct in ourselves' (Jung 1989:471). Jung elucidates: 'God can be called good only inasmuch as $\mathrm{He}$ is able to manifest His goodness in individuals. His moral quality depends upon individuals.' (Jung, Letters, vol. 2:314). For Jung, man is caught in the dynamism of the divine drama and we are now accountable for 'incarnating' the dark side of God. Seeing that Yahweh's moral paradoxical nature is 'not without consequences for humanity', since we too are 'obliged to struggle with the devil', in the form of inner conflict that can destroy man's integrity (Jung 1977:226, 230; also 186-189). Thus the divine conspiracy between Yahweh and Satan against Job served, psychologically for Jung, as an illustration as well as a warning.

\section{ANSWER TO JOB}

It is regrettable that you did not read my introductory remarks. You might have discovered there my empirical standpoint without which-I grant you-my little book makes no sense at all. Envisaged from a philosophical point of view without consideration of its psychological premise, it is sheer idiocy, from a theological angle nothing but downright blasphemy and from the standpoint of rationalistic commonsense a heap 
of illogical and feeble-minded phantasmata. But psychology has its own proposition and its own working hypotheses based upon the observation of facts, i.e., (in our case) of spontaneous reproduction of archetypal structures appearing in dreams as well as in psychoses. If one doesn't know of these facts, it will be difficult to understand what is meant by 'psychic reality' and 'psychic autonomy'. I agree with you that my statements (in Antwort auf Hiob) are shocking, but no more, rather less so, than the manifestations of Yahweh's demonic nature in the OT (Jung to G. A. van den Bergh von Eysinga, 13 February 1954, Letters, vol. 2:151-154).

After a long gestation period, ${ }^{10}$ Jung delivered Answer to $J o b^{11}$ in the spring of 1951 at the age of seventy-five, just after Aion, ${ }^{12}$ its older brother, had been published. In several of his letters Jung voiced the physical urgency and the emotional turmoil of the birth pangs in which the book came forth: it was 'during the fever of an illness' (Jung to H. Corbin, 4 May 1953, Letters, vol. 2:116) whereby 'I was plagued by my liver and had to stay in bed and write Job' (Jung to H. Württemberg, 30 August 1951, ibid:21); to his secretary, Aniela Jaffé, he described the process as having 'landed the great whale', but that it was nevertheless still going on 'rumbling a bit, like an earthquake.' (Jung to A. Jaffé, 29 May 1951, ibid:17-18). A few months later, with some distance he summarised the whole experience to her: 'if there is anything like the spirit seizing one by the scruff of the neck, it was the way this book came into being.' (Jung to A. Jaffé, 18 July 1951, ibid:20). Deirdre Bair recounts that it took Jung three months to revise the original text and that he wrote to the point of exhaustion (Bair 2003:528). Shamdasani remarked that neither the original manuscript nor the revised typescript are to be found in his papers at the ETH (Shamdasani 2012:210). Jolande Jacobi, one of Jung's collaborator,

\footnotetext{
${ }^{10}$ Shamdasani pointed out that the theology first articulated in Jung's Red Book found 'definite expression and elaboration" in Answer to Job (Shamdasani 2010:ix).

${ }^{11}$ Michael Fordham indicated that after Freud's Moses and Monotheism (1939) Answer to Job was the most significant work on the Bible that had been published addressing the religious implications of psychology (Fordham 1955:271-73).

${ }^{12}$ Aion is one of Jung's most complex books. The title refers to the two thousand year cycle and the astrological conception of the Platonic month. The Christian aeon coincided with the sign Pisces and now two thousand years later, it is about to enter that of Aquarius. In this book Jung explored the historical transformations of Christianity, including the symbolic figure of the antagonism Christ-Antichrist, and specially addressed how the Christian doctrine of the privatio boni did not sufficiently deal with the problem of evil.
} 
described him as 'moody in a rude and crude way, like a peasant... furious all the time' and his behaviour was 'like a woman giving birth to a child', or a man 'who let himself go like an uneducated child.' (Jacobi, in Bair 2003:528). To Marie-Louise von Franz, Jung remarked that he wished to have been able to rewrite all of his books apart from this one, with this one he was completely satisfied (von Franz 1998:161).

Jung's Answer to Job was a small—only 108 pages—but nonetheless highly controversial and provocative book that managed to attract harsh criticism at several levels. In the prefatory note, Jung wrote that for many years he hesitated to give a more complete answer on the numerous questions he had been asked by patients all over the world than the one he gave in Aion, due to the storm it would raise (Jung 1952, ATJ, CW11, 'Prefatory Note'). Aniela Jaffé has pointed out that had Jung used profane literature or patient's material to make his point about the ambivalence of the God-image, he might not have outraged his readers that much (Jaffé 1975:101). ${ }^{13}$ Answer to Job is Jung's only extended commentary on a biblical text. ${ }^{14}$ In it he discusses the Book of Job, the Epistle of St. John, the Book of Revelation, the apocryphal Book of Enoch (c.100 BC), the 'Sophia' of the Hebrew Bible and finally the dogma of the Assumption of the Virgin Mary (1 November 1950). It is beyond the scope of this paper to address all these issues, so the next section concentrates on Jung's account of the consequences of Job's engagement with of a God who could be psychologically experienced as evil as well as good poses to modern man.

Jung's psychological reflections in Job beyond doubt 'paid respect to the spirit of Protestantism', ${ }^{15}$ which he argued had 'the great

\footnotetext{
${ }^{13}$ A list of the earliest public responses to Antwort auf Hiob can be found in Bishop (2002:185, n113). For a Jewish study and a critique of Jung's Answer to Job see LévyValensi's Job: réponse à Jung. For a Jewish perspective on the psychological problem of Jung's Aryan Christianity in interpreting the Book of Job, see Corey's 'For the Sake of God: a Reply to Jung'. Corey also pointed out that Jung's dependence on Christian translations of the Bible and his ignorance of 'Oral' Scripture that supplements and amplifies the 'Written' Bible have distorted his understanding of Job. He explained: 'Job is, as the Talmud describes, 'a parable' of Israel's redemptive destiny written according to Oral Scripture by Moses himself at the time of the Revelation on Sinai' (Corey 1990:34).

${ }^{14}$ Jung interpreted the Christian tradition in two essays that were first published in the Eranos-Jahrbuch 1940-41 'A Psychological Approach to the Dogma of the Trinity' and 'Transformation Symbolism in the Mass'. His mature views on the psychology of religion were continued in Aion (1951) and lastly in Answer to Job (1952).

${ }^{15}$ Jung saw himself as a left-wing Protestant: 'I am definitely inside Christianity and, as far as I am capable of judging myself, on the direct line of historical development... If the Reformation is a heresy, I am certainly a herectic too.' (Jung Letters, vol. 2:334).
} 
task of reinterpreting all of the Christian traditions.' (Jung 1952, ATJ, CW11:§§752-755). In spite of the problems of Jung's psychologicalcritical approach, his treatment of scripture has found a place in biblical interpretation. ${ }^{16}$ Some specialists voiced their opinion regarding Jung's style. Theologian Kenneth Lambert pointed out early on that Jung's position mediates between Catholic exegesis and Protestant hermeneutics (Lambert 1955:106-107). Jung previously acknowledged that his position started from a positive Christianity, 'which is as much Catholic as Protestant... and tries to establish facts on which the two sides can unite' and complemented it by saying 'it is also the reason why I get kicks from both sides' (Jung Letters, vol. 2:348-9). Professor of theology James Heisig has called it 'psychotheology' and considers Jung's subtle motif in Answer to Job was to offer 'an alternative to atheism and pious submission', in spite of the 'exegetical distortion and dubious logic of his argument.' (Heisig 1973:231; Heisig 1979:82, 88). Protestant theologian Karl Barth argued that Answer to Job was a 'humanly gripping document' for the psychologist, but considered as a work of biblical interpretation Jung's work was 'unprofitable' (Barth, in Heisig 1979:182, n61; Bishop 2002:46). Jungian analyst Murray Stein argues that Jung's approach was a combination of 'hermeneutics and sermonics', and an Auseinandersetzung with the Biblical God. ${ }^{17}$ All in all, an unrestrained Jung argued his case against God at the same time he tried to understand and to explain the 'defectuosity of the Western God-image' to his readers (Jung Letters, vol. 2:434). God-image is a central concept in Jung's psychology of religion, and it is seen a symbolic expression of an inner image that transcends conscious understanding, it is an image of God and not as He is in himself. Jung describes it as: 'an engram or imprint which from the beginning of time has been the collective expression of the most overwhelming powerful

\footnotetext{
${ }^{16}$ The late Wayne Rollins, an Emeritus Professor of Biblical Studies in Massachusetts, created a new critical model in Biblical Studies and a new approach to Scripture in the 1960's. He has reflected extensively on the dynamics of psychological biblical criticism and has incorporated models developed in depth psychology giving special focus to Jung's insights of the value of psychological approach to scripture on biblical symbols. He termed this perspective 'psychological biblical criticism'. For more see: Rollins (1983; 1999). Other important scholars include: Miller (1995) and Kille (2001). Professor of Theology and writer of Fr. Victor White OP: The Story if Jung's White Raven (2007), Clodagh Weldon teaches Jung's Answer to Job to undergraduates in her course in biblical studies in the theology department at the Dominican University in Illinois (Weldon 2011:115-125).

${ }^{17} \mathrm{~A}$ word that roughly means 'a differentiating or clarifying encounter' with an idea or a person, it is most commonly used in the Jungian lexicon as 'coming to terms with' (Bishop 2002:93; Stein 2007:313; Schlamm 2008:110).
} 
influences exerted on the conscious mind by unconscious concentrations of libido' (Jung 1921, CW6:§412). ${ }^{18}$

To understand what Jung is doing in Answer to Job it is necessary to bear in mind a few important starting points in his interpretative framework:

1. Jung holds a Kantian subjective standpoint whereby all knowledge is mediated and we can only perceive God within the limits of our own psyche. ${ }^{19}$ Jung's basic definition of God is:

I make my patients understand that all the things which happen to them against their will are a superior force. They can call it God or the devil, and that doesn't matter to me, as long as they realise that it is a superior force. God is nothing more than that superior force in our life (Jung, in McGuire 1977:250).

His psychological analysis deals mainly with the image of God he observed in his own psyche and the psyche of his patients and refused to accept any sort of knowledge outside the psychological frame. Reinforcing his position as an empiricist,${ }^{20}$ he clarifies:

I can confirm and prove the interrelation of the God-image with the other parts of the psyche, but I cannot go further without committing the error of metaphysical assertion, which is far beyond my scope. I am not a theologian and have nothing to say about the nature of God (Jung to White, 5 October 1945, Lammers 2007a:9).

2. Jung conceived that the psyche exists in its own right as a phenomenal world in itself. His psychological stance reversed the rationalistic causal sequence, as he explains: 'instead of deriving these figures from our psychic conditions, [we] must derive our psychic conditions from these figures.'(Jung 1942, CW13:§299; also Jung 1931/1933, CW8:§§649-688). Psychic images are both a language and a dimension of inner experience, 
though not separate from the outer world. Hence, the mythical image of Yahweh is a representation of his reality in the psyche.

3. As a psychiatrist Jung valued the psychological significance of the symbolism of biblical narrative and was interested in how it could be translated into the life of the individual, since for him 'myths of a religious nature can be interpreted as a sort of mental therapy for the sufferings and anxieties of mankind in general' (Jung 1964:79). He interpreted the Book of Job as a 'landmark in the long historical development of a divine drama.' (Jung 1952, ATJ, CW 11:§560). For him Job 'is no more than the outward occasion for an inward process of dialectic in God.' (Jung 1952, ATJ, CW 11:§587). One could read Jung's narrative as a product of an active imagination with the biblical figures, i.e., a representation of a clash between man's consciousness (Job) encountering the unknown unconscious (Yahweh) (Schlamm 2008:109-121). ${ }^{21}$

4. Jung was of the conviction that his analytical psychology could contribute towards a process of religious evolution by ushering a new myth in the West (Dourley 2007:285); for this reason he felt it was his task to correct and complement the historical transformation of the Godimage: ' $[\mathrm{M}] \mathrm{y}$ work deals in the main with the transformation of Christian tenets within the Christian era.' (Jung, Letters, vol. 2:510f). Ann Lammers who wrote her $\mathrm{PhD}$ dissertation on the Jung-White relationship and was the editor of the Jung-White Letters (2007) suggests that Jung 'operated both as wrecker and as a builder, tearing down parts of the standing order because he wanted to reconstruct it' (Lammers 1994:155). In a letter to Victor White in 1953 he used the following metaphor to clarify the architectonics he had in mind: 'Nobody will be so foolish to destroy the foundations when he is adding an upper story to his house, and how can he build it really, if the foundations are not properly laid?' (Jung, in Lammers 2007a:222).

Having now laid out some of Jung's methodological assumptions we can perhaps begin to appreciate the meaning he extracted from the images embedded in the Book of Job; considering that he believed that they pointed to a development beyond Christianity and contained a new dispensation for modern man (Edinger 1992a:59-60).

In Jung's fiery revision of Job, he appeals to the reader to follow him in his intense confrontation with Yahweh. Moreover, by taking up the

${ }^{21}$ On active imagination, see Jung (2009, RB:209; 1954, CW14:§706; 1916, CW8:§§

131-193); von Franz (1997:163-168); (Hannah 2001:16-21); Hull (1971:115-120). 
crucial question: 'whence evil?' Jung seemed to be articulating several 'answers': Yahweh's answer to Job, his own answer to both Jewish and non-Jewish patients in face of the war, and, last but not least, his most personal answer to and powerful argument with Victor White (See Dourley 2007; Stein 2007a). Both the content and intention of Jung's psychological reflexions is to bring the ambivalence of the Judaeo-Christian God image to the spotlight. The essence of his interpretation of Job's encounter with the paradoxical nature of God goes as follows:

Yahweh is personally involved in human suffering due to his relationship to Satan (ATJ, CW11:§616). He is both unaware of his brutality and insensibility to all the suffering he had inflicted, in spite of being omniscient. Job's submission is not because God's justice is a mystery not to be understood in human terms, but is rather a legitimate critique of his injustice (ATJ, CW11:§603). Yahweh's answer coming out of the whirlwind is no real answer; he showed Himself to be a force of nature behaving just like one of the crocodiles or the Leviathans he had created (ATJ, CW11:§§599-600). Yahweh is to blame for his misuse of power and cruelty by betraying Job. Job is certain that he has not sinned and is also certain that there is another side of God to which he pleas in the hope of finding an 'advocate' in God against God himself (ATJ, CW11:§567). By standing his ground defending his sinless position, Job was able to see God's double nature in which both His light and dark sides were exposed (ATJ, CW11:§§584, 608). This realisation produces a radical transformation: Yahweh is unfaithful, not Job (ATJ, CW11:§616). This precise act of consciousness elevates Job - a mortal man is raised by his moral behaviour 'above the stars in heaven'; the creature has surpassed the creator (ATJ, CW11: $\$ 595,640$ ).

Yahweh suffered a moral defeat in failing to corrupt Job (ATJ, CW11:§617). Now that God has done man wrong a compensation begins to take shape in the psyche for Job's undeserved suffering: God must regenerate and become human himself (ATJ, CW11:§§624, 631, 640). But then a decisive separation takes place in the God-image-His dark side is split off because Yahweh identifies only with His light aspect when $\mathrm{He}$ incarnates on earth in Christ. Although Christ did become man his nature is more divine than human, he was not born of human father and his mother was a virgin (ATJ, CW11:§626). It is only at the moment when Christ cried out on the cross: 'My God, My God why hast thou forsaken me?' that God experiences what it means to be mortal (ATJ, CW11:\$647). In this position, suffering and experiencing evil in the flesh God finally gives the answer to Job (ATJ, CW11:§647). Yahweh did not spare his son, on the contrary 
He expected a human sacrifice and much in the same way, mankind now stands where Job and Christ stood - abandoned and with the paradoxical nature of God weighing heavily upon us. Due to the incomplete incarnation of Yahweh in Christ, who embodied only His good side, a new task is set on mankind: the resolution of the divine antinomy must take place in man (ATJ, CW11: $\S 655,657,690$ ). Redemption does not come through faith in Christ, who has vicariously saved us, but in the awareness of the inescapable partnership of the divine and the human sharing responsibility for both the good and evil in the world (ATJ, CW11:§§659, 693).22

Job's pivotal role served to further the Jungian myth of the continuing incarnation as a symbol for psychological development. Thus, by rejecting and revising man's submission to a loving God, Jung on the one hand added a new level of understanding to the experience of suffering, and on the other hand he questioned the Church's teachings that the incarnation was a unique historical event. He argued that it had not ceased with the Ascension but continued through the Holy Spirit in man. He called this process the 'Christification of many', ${ }^{23}$ whereby Christ is to be seen as a pattern to take place in each man and God is to incarnate in the ordinary human being. As could be expected, Jung's insistence in placing good and evil as part of the essence of the creator Himself and his view of a new psychological dispensation for modern man were taken as an offense against centuries of theological reflection.

\section{ANSWER TO JUNG}

... Generally speaking it $[$ Answer to Job] cannot be read. For Jung deliberately reads the Scriptures through a pair of highly distorted spectacles. Although he is not writing of God but of God-images, he is not writing directly even of Job's images of God, but rather of his own images of Job's images ... Even an instructed Christian may expect an explosion when an adult, whose religious development had become fixated at the

\footnotetext{
22 For a more detailed psychological interpretation of Jung's Answer to Job, see Edinger (1992a:59-90); Evans (1954:5-26); Stein (2003:1-18).

${ }^{23}$ Jung used this term for the first time in the last paragraph of Job, but this idea has its seed in the concept of his interpretation of the imitatio Christi in his Red Book. He has then elaborated it in the Collected Works ever since his lecture at Eranos 'On the Psychology of the Idea of the Trinity' in 1940 (Jung 1952, ATJ, CW11:§758; 2009, RB:292-6; Heisig 1979:184, n88).
} 
kindergarten level of bourgeois morality ... becomes confronted with the realities of life, of the ways of God both in the Bible and in contemporary events. It is understandable that he feels a close kinship with the disillusioned, tortured Job ... The violence of the abreaction is understandable ... his grievance is hardly adult ... the only reaction is that of the spoiled child (White, in Lammers 2007a:353-354).

This was the death knell of the long-standing relationship between Victor White and Jung. White had been Jung's most important theological collaborator for over fifteen years, and in a short period of time he had become a very close personal friend. Within a year of their first correspondence, White made the first of ten visits to Bollingen, the first was in August 1946 and the last one was in July 1952. The last time they met was in June 1958 but in Küsnacht this time. Jung made White full part of Jungian intellectual circle, he was invited to speak at Eranos conferences and in 1947 he also was invited to be one of the founding members of the C.G. Jung Institut in Zürich. Adrian Cunningham, Professor of Religious Studies and a Victor White specialist, pointed out in an interview:

Victor White was one of the very few, possibly the only person in the inner circle who really stood up to the old man [Jung], and slugged it out over a period of years until they were both exhausted with it (Arraj 2015).

Jung expressed his grief about White's death: 'As I have so earnestly shared in his life and inner development, his death has become another tragic experience for me.' (Jung, in Lammers 2007a:303). The trajectory of Jung and White's personal relationship is reflected throughout their discussion on the relationship between psychology and religion in The Jung-White Letters. The letters are authentically presented in a 'close-knit' dialogue with no editorial improvements. Both men were experts in their fields and in the thick of post-war years they hoped to create an alliance in which to foster spiritual health in modernity and to 'transform the Christian West.' (Lammers 2007b:253). However, as the Jungian-Christian dialogue progressed, their enthusiasm turned to rejection and collaboration into controversy, to the point of no return. Their incompatible views on God and evil could not be reconciled and the tensions that were present from the start became impossible to overcome following the publication of the English translation of Answer to Job in 1954. Lammers broke down 
White and Jung's disagreements in three levels: doctrine, hermeneutics and epistemology. (Lammers 1994:18-24).

Victor White (1902-1960) was a catholic convert and teacher of dogmatic theology at the Dominican school, Blackfriars in Oxford, and due to a crisis of faith he opened up to Jung's thought, starting analysis in London in 1939. White described this crisis of faith as:

I am by profession a theologian. But I am a theologian to whom, something happened. Suddenly, or perhaps not so suddenly, theology ceased to have any meaning to me at all ... and so I was forced to turn to the psychologists ... I did have a hunch that the method and approach of Jung might have something that spoke to my condition (White, in Weldon 2007:16).

White also attended a study group with a few of Jung's earlier followers facilitated by his analyst, the anthropologist John Layard (1891-1974), who was trained by Jung himself (Lammers 2007b:255). White had been studying Jung's work for five years when, encouraged by Gerhard Adler (1904-1988), ${ }^{24}$ he wrote to Jung for the first time just after the end of the war in 1945, enclosing a few essays in which he connected church doctrines and Jungian psychology: 'The Frontiers of Theology and Psychology (1942), 'St. Thomas Aquinas and Jung's Psychology' (1944), 'Psychotherapy and Ethics' (1945), and a 'Postscript' to the latter, reviewing a book by a Freudian psychotherapist on the ethical implications of psychotherapy. (Lammers 1994:35). Jung had just celebrated his $70^{\text {th }}$ birthday and saw White's arrival as an invaluable contribution. Jung described this: 'Excuse the irreverential pun: you are to me a white raven inasmuch as you are the only theologian I know of who has really understood something of what the problem of psychology in our present world means.' (Jung to White, in Lammers 2007a:6). He had been waiting for years for a theological partner with whom 'to discuss on equal terms matters of vital importance' and to help him refine his interpretation of Catholicism (Jung, Letters, vol. 2:450n; Lammers 1994:36), which Jung valued very much, since for him it was a 'treasurehouse of patristic wisdom' (Jung, in Lammers 2007a:5). Ann Lammers has called attention to the fact that even though White was 27 years younger than Jung he was not, in any sense, the junior

\footnotetext{
${ }^{24}$ Gerhard Adler, of German-Jewish descent, was the editor of the English translation of Jung's Collected Works, the founder of the Association of Jungian Analysts, co-founder of the Society of analytical Psychology and a founding member of the International Association for Analytical Psychology.
} 
partner in this encounter. ${ }^{25} \mathrm{He}$ could read 'fairly easily' French, German, Spanish, Italian, and Latin and by 1940 White was known as a first-class Thomist: he was among the English Dominican scholars who worked on a new, annotated translation of the Summa Theologiae, ${ }^{26}$ and was granted in 1954 an STM (Master of Sacred Theology), the highest theological degree awarded since medieval times as 'a sign of exceptional merit as a scholar and teacher of theology.' (Lammers 2007a:16, n50). White soon expanded his knowledge and also became versed in analytical psychology, he held the opinion that religion and psychology 'shared a common territory and a great many concerns ... and this common territory is what religion calls the human soul and what psychology calls the human psyche.' (White, in Cunnings, 'Victor White, a Memoir', in Lammers 2007a:321). In his encounter with Jungian psychology White hoped to construct a synthesis and build a theoretical bridge between the two systems of thought, whereby Thomism would supplement and complete analytical psychology with Christian truth and psychological insight would be used as a pedagogical tool for the church and its clergy (Lammers 1994:55, 71; Stein 2011:601).

Attracted by the religious element in Jung's system, White genuinely believed that he could supplement its metaphysical deficiency (Weldon 2007:20, 22). He wrote several articles and reviews on Jungian psychology clarifying and articulating both the differences and points of contact between theology and psychology. ${ }^{27}$ An important common ground they shared was a far-reaching concern with the suffering human being, since both disciplines accept practical responsibility for the cura animarum (Jung, Letters, vol. 2:553). Another point that brought the clergyman and the psychologist 'shoulder to shoulder' was the question of good and evil

${ }^{25}$ For an account how Jung's relationship with White is an attempt to continue the theological debate with his father and for a parallel between the Freud-Jung relationship with the Jung-White relationship see Stein (2007:303-14).

26 The Summa Theologiae was the work which immortalised Thomas Aquinas (12251274). It is a manual of Christian doctrine and a textbook for the study theology; it has been used for more than seven hundred years. Aquinas systemised theology establishing the relations between faith and reason. St. Thomas is considered as the 'Christian Aristotle' for combining Aristotelian philosophy to ecclesiastical orthodoxy.

${ }^{27}$ White's main writings on Jungian psychology were: 'The Frontiers of Theology and Psychology', Lecture 19 in the Guild of Pastoral Psychology (1942); 'The Analyst and the Confessor' in The Commonweal: A Review of Religion, Politics, and Culture (1948); 'Eranos': 1947/1948' in the Dominican Studies (1949); God and the Unconscious (1953); 'Jung on Job' in Blackfriars (1955); God and the Unknown and other Essays (1956); Reviews of 'The Collected Works of C.G. Jung: Volume 1 and Volume 5' in Blackfriars (1957); 'Critical Notices: Psychology and Religion, by C.G. Jung' in the Journal of Analytical Psychology (1959); Soul and Psyche: An Enquiry into the Relationship of Psychotherapy and Religion (1960). 
(Jung 1932, CW11:§504). Regrettably, the idea of a compatible theoretical coordination tragically failed precisely as they tried to educate each other on their opposing views about the nature of evil.

But before we move to the next section it will be useful to contextualise the background of their dispute, since lying behind them there were major contrasting points of departure. The first one was a theoretical barrier of two totally different philosophical fields of association: White was a traditional logician, his thinking grounded in Aristotelian intellectualism, in St. Augustine and Thomas Aquinas's philosophical thought. By contrast, Jung's thinking had been shaped by Kantian subjectivism, post-Schleiermacher Protestantism and Jamesean pragmatism (Lammers 1994:16-17, 114-132). No wonder that the philosophical discrepancies of authority of dogma, supported by tradition versus authority of the individual, endorsed by experience would become an 'insurmountable obstacle' between them.

Second, White was bound to ecclesiastical authority by his vow of obedience. Jung, in turn, was in a privileged situation with a great degree of professional autonomy, which allowed him to be independent "without endangering his very existence' (Jung, in Lammers 2007a:264). This point is particularly important to stress, as White's association with Jung would have serious consequences for him as a Thomist scholar. The political scenario of Catholic scholarship in White's time was an oppressive one, with neo-scholasticism, the modern revival of Aquinas arising in the mid nineteenth century as a reaction against secular knowledge. This conservative movement endorsed a return to the scholastic theology of the thirteenth century as a way to protect against the heresy of 'Modernism' and to further condemn those who contradicted the magisterium. ${ }^{28}$ Episcopal vigilance, the Imprimateur permission for publication; condemnation of censured titles with their inclusion in the Papal Index, swearing of the antimodernist oath and excommunication were some of the drastic measures used to enforce obedience to ecclesiastical authority. ${ }^{29}$ White, for his part, was among the theologians who tried to create a more vital theology; he

\footnotetext{
${ }^{28}$ The war against modernism was an institutional battle within the Catholic Church generated by the fear of historical change 'infected with Kantian spirit' that could endanger faith and morality. In 1864 Pope Pius IX published the Syllabus of error against faith. In the twentieth century Pope Pius X characterised modernism as the 'synthesis of all heresies', he condemned Catholic scholarship with modernistic tendencies and ordered all clergy to compulsory swear their loyalty to the antimodernist oath. See Livingston (1997; 2000).

${ }^{29}$ For an example, see http://w2.vatican.va/content/pius-x/en/encyclicals/documents/ hf_p-x_enc_19070908_pascendi-dominici-gregis.html
} 
was a 'modern Thomist' who identified with Aquinas not as an ally against modernity, but as a model for integrating different understandings of truth. Aquinas himself found truth also in the Muslim philosopher Avicenna and Averroes, the Jewish Rabbi Maimonides and the pagan philosopher Aristotle (cit. in Weldon 2010:178). It was this predisposition that made him not only susceptible to Jung's psychology, but also to theological conflicts within his Order and with the impositions of the Roman Church.

\section{THE ARENA OF DISPUTE: THE SCHOLASTIC AND THE JUNGIAN VIEW ON THE PROBLEM OF EVIL}

The doctrine of evil as the privation of good appears to have been first proposed by St. Augustine in the fifth century, particularly in his defense of monotheism against Manichaean dualism, which viewed good and evil as mutually exclusive principles; the philosophical roots to this idea, however, reach back to Aristotle. ${ }^{30}$ But it was Aquinas who later developed and systematised the doctrine of the privatio boni more fully in the thirteenth century (Aquinas 1993:284-289; Davies 2001:55-119). This definition rests on the conviction that God, as the summum bonum, is a supremely good God who created all things, but not evil. Evil has no ontological status, it is not a created being and has no source of power; it can be understood as a lack, a distortion or even a parasite of the good. The denial of the substantiality of evil and its subordinate relation to the good still is 'widely held and taught in Catholic tradition' (Lammers 1994:289, n29). Furthermore, in both classical philosophical and theological notions of evil as privation there is a phenomenon of reduction and its interpretation is wholly negative. Conversely, as mentioned in the earlier part of this paper, for Jung, evil is a positive component of reality and an equal contrary to good - the symbols of Christ and Satan being the paramount examples of the split between good and evil and of the contradiction of the Christian myth. White repeatedly tried to clarify the Thomist logic to Jung in letters and written papers on the subject: 'Good and evil, in the abstract, are indeed opposites, but they prove on reflection to be not two positive contraries - äquivalente Gegensätze as Jung calls them-but contradictories.' (White 1960:153). He could agree with Jung that they were opposites, but not equivalent contraries.

In the beginning White thought that the difference was 'unimportant

${ }^{30}$ In Metaphysics Aristotle argued that goodness is the governing principle of the universe, he listed various types of privation and evil as privation of good. See Aristotle Metaphysics, book IX; as for St. Augustine's view, see Augustine Confessions, book III. 
and academic', but as their discussion on these matters took shape he came to realize that it 'affected his value-judgements of almost everything.' (White, in Lammers 2007a:182). Jung's ambivalent God-image disturbed his belief and the orthodox depiction of a perfect and good God beyond the opposites of good and evil, until in 1949 White, for the first time, publicly corrected Jung's 'inferior theology' in his Eranos lecture 'Über das Selbst':

An elementary study of (for instance) St.Thomas's sections in the Prima Pars On the Good, On the Goodness of God, On Evil, and On the Cause of Evil, should suffice to dispel Dr Jung's misunderstandings and misgivings, and to supply a metaphysic which would account for the phenomena which concern him at least as satisfactorily as the quasi-manichaean dualism which he propounds. These somewhat confused and confusing pages might be dismissed as just another infelicitous excursion of a great scientist outside his own orbit ... It is regrettable indeed that, supported only by such naive philosophizing, the most pregnant movement in contemporary psychology should be burdened with an irrelevant association with Gnostic dualism (White 1949:399).

This happened to be a crucial turning point in their relationship and warning of a 'storm to come' - the impasse over the nature of evil had spilled over from their private correspondence into the public arena: Jung had more forcefully attacked the metaphysical definition of evil in his lecture 'Über das Selbst', which was then followed by White's critical review; Jung's lecture later became chapters four and five of Aion, where he responded to White's criticism in a footnote:

My learned friend Victor White O.P. ... thinks he can detect a Manichean streak in me...In addition to this my critic should know that how very much I stress the unity of the self, this central archetype which is a complexio oppositorum par excellence, and that my leanings are therefore towards the very reverse of dualism (Jung 1951, CW9ii:§112, n74).

From this point onwards their correspondence got 'caught up in linguistic disputes' about God and evil in a most 'obstinate point of difference.' (White 1960:75). White continued to propose theoretical 
and conceptual distinctions, but the grounds of his arguments were not sufficient to convince Jung. They were still friends, but inevitably, one became more and more critical of the other. The following section addresses the course of their controversy chronologically, revealing the crescendo of the process until its culmination in White's 'Jung on Job'. Within six years both men would be dead, reconciled as friends in the end, but evil remained an intellectual dispute never to be resolved.

In March 1952 White published a series of revised lectures and essays in his book God and the Unconscious. Still making an effort at bridge-building, but nevertheless bluntly criticising Jung, White carefully considered:

There are very understandable reasons which have made it difficult for theologians and philosophers to take Jung's work seriously. The obstacles to understanding are considerable, and should not be minimized ... Regarding evil as having (apparently) some positive existence and reality of its own, Jung logically enough requires the admission of evil, not only into the "self", the human totality, but also into the Godhead itself ... which orthodox Christians must find quite inadmissible (White 1952:65, 75).

Jung, who had written a forward for this White's book, continued to address some of the important differences between psychology and theology and used this opportunity to explain his criticism of the doctrine of the privatio boni once again: 'Hence I feel at liberty to avail myself of the right of free criticism, so generously offered me by the author, and to lay my argument [on the privatio boni] before the reader.' (Jung 1951, CW11:§456). At this point in spite of refusing to agree with Jung and defending the classic doctrine, White still considered the possibility of reaching some understanding after the overcoming of 'strong resistances':

Jung has our keenest support and sympathy in deploring the minimizing of evil which leads to its repression, with its devastating results for the individual psyche and society; but we are unable to find evidence that the conception of the privatio boni has contributed to this (White 1952:75-76, n1).

Two months later, in the Spring 1952, Jung sent White the manuscript of Antwort auf Hiob and White's first response was very positive: 'Thank 
you a million for "Hiob"... I can hardly put it down. It is the most exciting and moving book I have read in years.' Then, in the same letter he complained: 'I do wish we could somehow resolve this deadlock about privatio boni,' and towards the end he concluded in a most warm way: 'I'll be eternally grateful to you, whatever befall this difficulty with privatio boni.' (White, in Lammers 2007a:181-182). As shown in the example of the letter above, their intellectual debate carried on in the midst of sharing profound mixed feelings and anxieties between friends. Throughout this year their discussion concerning the problem of evil reached its peak. ${ }^{31}$

During the years of 1953 and 1954 White was again plagued by doubts considering whether to stay in or leave his Order and the Church and confided to Jung:

... their God simply isn't my God any more: my very clerical clothes have become a lie ... I am just indescribably lonely, and it's some relief to me to tell you ... I must confess there are times when I wish to heaven I had never heard of your psychology (and some of your disciples!); and yet I tremble to think what would have happened if I hadn't! (White, in Lammers 2007a:216-217).

Jung's psychology held an attraction-rejection paradox for White: the closer he got to understand it, the more threatening it was to his faith and the more incompatible it was to his theology. Supported by Jung, White decided to remain a Dominican and signed the anti-modernist oath once again. Soon after this he received his STM degree, a prerequisite for his next career move as Regent of Studies in Oxford. This was a position that White very much looked forward to, as he would be responsible for the curriculum and training of new generations of Dominicans and, more importantly, he would have 'great influence' in how Aquinas would be taught at Blackfriars. Regrettably, because his professional life had been entangled with his friendship with Jung, a new conservative neo-Thomist was appointed to the job instead, and White was sent to California 'in exile' for five months..$^{32} \mathrm{He}$ was never to teach at Oxford again.

Meanwhile, the ongoing polemic with Jung and evil continued

\footnotetext{
31 See especially their correspondence in April 1952, 30 June 1952 and 9 July 1952. White also stayed in Bollingen for ten days in July 1952 where the discussion between them carried on. Cit. in Lammers 2007a:293, n5.

${ }^{32}$ White left Oxford on 16 October 1954 and went to St. Albert's Dominican House in Oakland, California. Lammers speculates that the moving force behind the decision came from White's own Provincial. See Lammers (2007a:247-2488, n88, 89, 90, 91, 92; 2007b:264-265); Weldon (2007:179-181).
} 
in California, and both men began to anticipate the possible difficulties Answer to Job would bring in. In January 1955 White expressed:

I am frankly relieved that "Answer to Job" has not yet appeared in the USA! ... Already of course I am getting perplexed and indignant letters from England asking "What the hell..." It cost quite some sleepless nights, trying to write an article to explain what I think ... I hope you find the result (which I will send you if and when is published) not too distressing; and especially that you will take into consideration for whom it is written (White, in Lammers 2007a:254).

To which Jung replied: 'I know you will have some difficulties when my "Answer to Job" becomes public. I am sorry.' (Jung, in Lammers 2007a:256). But none of them would have imagined how deeply the blow would cut and how painful the consequences would be for both of them. In March 1955 White wrote his review 'Jung on Job' for the journal Blackfriars. In it he publicly charged Jung with taking personal interpretation of scripture to an extreme, and in what amounted to an ad hominem attack included called the book 'destructive and childish', and accused Jung of being paranoid and questioning:

... is he, after the manner of his own "Yahweh" duped by some satanic trickster into purposely torturing his friends and devotees? Or is he, more rationally, purposely putting them to test to discover how much they will stand rather than admit the fallibility of their master - or how many, more Job-like, will venture to observe that the Emperor has appeared in public without his clothes? (White 2007:352). ${ }^{33}$

Some of the reasons why White lost his 'rhetorical control' have been pointed out by several scholars (Lammers 1994, 2007a; Weldon 2007; Cunningham 1981, 2007). First of all, although he had been trained as a priest to obey, he had not fully accepted the humiliation of having his appointment as Regent set aside by the office in Rome. Second, he was extremely frustrated after having spent ten years in attempting to translate Jungian psychology to theologians to have his efforts hindered, and third he was deeply hurt for no longer being trusted as teacher within his Order.

33 In 1959 White also criticised Job in his review of Jung's Psychology and Religion, but in a more balanced way this time. 
Thus, the anger White felt for having his career jeopardized within his Order was outwardly directed at Jung (Lammers 2007a:258-265; 1994:101-109; Weldon 2007:181-187; Rutte 2009:308-310). Nevertheless, White is not consistent in his attack and before the review was published he wrote to Jung asking for forgiveness: '[...] there are some passages I would now wish to have kept to myself [...] and I am penitent that I have laid my criticism on so thick.' (White, in Lammers 2007a:259-260). Two weeks later Jung responded to White:

I am grateful for the fact that you call me to order and that your judgment-be it correct or not—does not spare me, so I assume God will listen to a mortal voice, just as much he has given His ear to Job, when this little tortured worm complained about His paradoxical, amoral nature. Just as Job lifted his voice so that everybody could hear him, I have come to the conclusion, that I better risk my skin and do my worst or best, to shake the unconsciousness of my contemporaries. [...] in our time everything is at stake, and one should not mind the little disturbance I am causing [...]. I have hesitated and resisted long enough, until I have made up my mind to say what I think (Jung, in Lammers 2007a:261-262).

Jung then gave White a psychological reading:

Your criticism, of my motive concerning "Job" is certainly unjust and you know it. It is an expression of the mental torment you had to undergo in USA — and in Europe [...]. Having chosen the life of a monk you have separated yourself from the world and exposed yourself to the eternal fires of the other. Somewhere you have to pay the toll either to Man or to God and in the end you will discover that both overcharge you (Jung, in Lammers 2007a:263).

Here Jung pointed out that because White was 'being fed by an institution for services received' he had to be cautious of the way he expressed himself. An important point that confirms this was made by another priest who was expelled from the Dominicans as he was advised by his canon law attorney: 'You must remember that taking on the Vatican is like standing in front of a train. You cannot win; no one ever has.' (Rutte 2009:50). White remained in his Order and realised that it was 
impossible to reconcile the Jungian position with traditional theology. The ramifications of their differences were too deeply rooted and there was no possible compromise: for White theology was 'the queen of sciences'; thus it had primacy over psychology and - God, not the psyche - had the ultimate authority (see Weldon 2007:219).

Despite all this, White apologized for attacking Jung so harshly: 'I do indeed deeply regret having published that article without any regard for your feelings or my own feelings for you.' (White, in Lammers 2007a:268). He, nevertheless, still continued to write antagonistic letters, and one of which included a list of several 'Problems Arising from the Publication of Answer to Job':

\begin{abstract}
Answerto Job is presumably to be read, not as an essay in theology, metaphysics or exegesis, but in practical psychology... What then is its practical psychological content and implication? First and foremost it seems to be this: God (not me) is unconscious, divided in himself, moody, capricious, purposeless-but notably evil as well as good. Evil is an ultimate and irreducible constituent of reality to be accepted - not a privation which can be supplied by good, or out of which good can be brought. My 'evil' is no more my concern. It is 'all God's fault' and I can and should lay all the blame there ... the personal shadow is transferred to the 'divine', 'collective' sphere and left there. If these are not the psychological implications of the book, they are the obvious ones which in fact are being drawn, and urgently need the author's corrections (White, in Lammers 2007a:268-
\end{abstract} 272).

Thus in spite of voicing his regret towards his friend, and later having removed several passages in the edited version of 'Jung on Job' in his book Soul and Psyche (1960) (White 1960:233-240), the publication of White's review was a blow that cut both ways: he separated himself definitively from Jung's framework and damaged the friendship for good:

For myself, it seems that our ways must, at least to some extent, part. I shall never forget, and please God I shall never lose, what I owe to your work \& your friendship ... 'I hope you do not doubt my friendship, wrong-headed \& heartless though it sometimes is. Poor Job at least had friends-however stupid (White, in Lammers 2007a:273). 
White continued to write to Jung (three letters in 1955, one in 1956 and two in 1958), but Jung did not reciprocate anymore. At this period Emma Jung was diagnosed with terminal cancer ${ }^{34}$ and the grieving Jung, consumed by her illness, asked White: 'Please put conventionality aside and do not feel under any obligation... a conventional call means nothing to me, and a straightforward talk may be painful and not desirable.' (Jung, in Lammers 2007a:266). White's last effort to clarify his polemic with Jung was the essay 'Kinds of Opposites' which appeared in the Fetschrift in 1955 for Jung's $80^{\text {th }}$ birthday, where he discussed Aquinas's treatment of good and evil and provided the vocabulary of his main intellectual difference between him and Jung (Lammers 2007a:255-256, n10). It was written within weeks of his public reaction to Answer to Job.

After a three-year break the two men met briefly and for the last time in 1958 in Küsnacht. In April 1959 White had a near fatal scooter accident that seriously impaired him, which coincided with the Roman Curia taking steps towards suspending the sale of his God and the Unconscious. ${ }^{35}$ After hearing about White's accident Jung contacted him for the first time after their fall out: 'Concerning my doubts about your general attitude I must mention, in self defense, that you expressed yourself publicly in such a negative way about my work that I really did not know what your real attitude would be.' (Jung to White, 21 October 1959, in Lammers 2007a:282). To which White replied:

I am somehow moved to send you the assurance of my love for you... I have been, \& still am, sorely perplexed to understand when \& where I am supposed to have done this... and, although [there are] matters on which I cannot see eye to eye with you, I would never question your sincerity (let alone publicly), as you have appear to question or deny mine... (White to Jung, 18 March 1960, in Lammers 2007a:283-284).

Both men took steps towards reconciliation but still could not avoid the points of discord.

In March 1960 White was diagnosed with intestinal cancer and

\footnotetext{
${ }^{34}$ In the spring of 1955 Emma Jung discovered that her cancer was inoperable, she was able to take part in Jung's 80 $0^{\text {th }}$ birthday celebration and died on 28 November 1955.

${ }^{35}$ White fractured his skull, four ribs, a scapula, lost his vision on the left eye and the left hearing. When his book was out of print Rome attempted to have its Imprimatur withdrawn because of the preface written by Jung, but the book was not suppressed in the end (Weldon 2007:210, 293, n137, 197; Lammers 2007a:110-111).
} 
Jung, who was not that well himself, having had a heart embolism a month earlier, and not aware of White's cancer being terminal, continued their dispute. This time he addressed White as Job, perhaps suggesting that the painful experiences White was going through had to do with the dark side of Yahweh:

Since you are very much in the situation of the suffering Job I shall not play the role of his friends, not even of the wise Elihu. I humbly submit the suggestion, you might apply your personalistic point of view to your own person.

After a long psychological explanation Jung ended the letter in a most friendly way: 'I think of you in ever lasting friendship ... thus I ask for your forgiveness, as it is incumbent on one, who has given cause for scandal and vexation.' (Jung to White, 25 March 1960, in Lammers 2007a:284-286). White was extremely pleased to hear from Jung again and during the final weeks of his life he wrote two more letters still striving for some intellectual closure. In the first one he explained that once Antwort auf Hiob had been published it had to be considered objectively because it raised

very many difficulties and problems for many people besides myself... I think these questions cannot be disregarded by anybody who is keen on spreading and continuing the wonderful work you have begun, and which "Antwort" seems implicitly to repudiate (White to Jung, 6 May 1960, in Lammers 2007a:289291).

In the last letter, written two days later, White concluded:

I am more convinced than ever of the importance of your pioneer work for humanity, even for those who cannot agree with every word you say but have to take part in the "dialectic discussion" with you ... I do not know if it is true that you have been a "petrus scandali" to me (as you say you have), but to the extent that you may have been, I think that I can honestly say that I am grateful for it (White to Jung, 8 May 1960, in Lammers 2007a:291-292).

Victor White died two weeks after this letter, at fifty-seven years of 
age and Jung outlived him by just a year. ${ }^{36}$

The trajectory of the Jung-White personal relationship and their intellectual collision over the nature of evil led to substantial losses and suffering. ${ }^{37}$ The degree of their involvement, the intensity of their discussion and the magnitude of their interaction led to the psychological hypothesis that the crucial events that happened around them were not unrelated to the phenomena they were discussing. Lammers has written of a force-field in which they were both caught and theirs was a shared tragedy (Lammers 2005:9). White scholar and chair of the theology department at University of Lancaster, Adrian Cunningham, believes that White's life was shortened by the discussion and disagreements with Jung (Cunningham 1981:324). Catholic priest and Jungian analyst, John Dourley sustains Jung's view ${ }^{38}$ that White could not make the transition offered by psychology and chose the transformation of death (Dourley 2009:85).

So is it valid to speculate that the Jung-White polemic became a living testimony of the 'pleromatic drama for which mankind serves as a tragic chorus', as discussed in Answer to Job? (Jung 1952, ATJ, CW11:§686) What it is possible to affirm is that the impact of Jung's argument against the privatio was enormous for White. With the publication of Answer to $J o b$ the problem of evil had been forced onto God and it was impossible for White to accept that there was evil in the transcendent God of his faith. Goodness and Being were interchangeable in White's theology and Jung's insistence on making evil real, made it good. ${ }^{39}$ The implications of such a position, of understanding the split between good and evil as reflective of a contradiction in the creator himself, proved to be incompatible with

\footnotetext{
${ }^{36}$ Victor White died on 22 May 1960 and Jung on 06 June 1961.

${ }^{37}$ It started with Jung's heart embolism a year after meeting White in 1946, followed by the gradual wrecking of White's career, then Emma's Jung terminal cancer and death in 1955, White's near fatal motor scooter's accident in 1959, Jung had another heart embolism in 1960, finally White's cancer and early death in 1960.

38 Jung described this in a letter about White: 'I have now seen quite a number of people die in the time of a great transition, reaching as it were the end of their pilgrimage in sight of the Gates where the way bifurcates to the land of Hereafter and to the future of mankind and its spiritual adventure.' (Jung, in Lammers 2007a:306).

${ }^{39}$ Lammers offered an important conceptual distinction on the problem of evil in Jung's writings that would have helped White to better understand Jung. She distinguished two types of evil: the evil of myth and the evil of history. For Jung, the former holds a dynamic interplay of the opposites that are in need of each other, like the left and right hand of God and the symbol of yin and yang. The latter consists of all the horrors of historical events and wars, which show the human capacity for destructive actions and actual harm. 'Mythic evil must be attended to, so that historical evils might be fought against.' (Lammers 1994:180-184).
} 
his religious view, since the belief in God's goodness is absolutely vital and central for Christian faith. In Job Jung corrupted the Christian truth that evil arises with men not in God, and inverted the traditional doctrine of man in the image of God, to God in the image of man. Thus Jung's heretical interpretation posited the idea that mankind is set against the polarities and the contradictions of the God-image and, by the same token, they correspond to positive and negative aspects of human nature.

For White the transformation of the Western God image applied to human beings not to God, but for Jung the Western God-image had both a dark side and potential for transformation. Even though their discussion 'generated more heat than light' (White 1952:75, n1) and the distance between their thoughts could not be bridged, it was the incompatibilities of their viewpoints and their efforts in educating each other that helped Jung formulate his mature thought (Stein 2007:x). White, as a catalyst and the 'spark that ignited' (Stein 2003:16) Jung's passionate disapproval of the privatio boni and their extended dialogue, appear to have been a 'formative influence' on Answer to Job and on Jung's late alchemical work (Dourley 2007:283). Notwithstanding White's accusations, Jung never was a dualist, and was 'deeply convinced of the unity of the Self' (Jung, in Lammers 2007a:142); indeed his psychology responded to the dualism that he observed 'lurking in the shadows of the Christian Doctrine.' (ibid.). One perhaps could say that his religious imagination of the Self as a complexio oppositorum makes him a dual-aspect monist whereby the evolving myth of the necessary incarnation of God no longer attributes the opposites 'God' and 'man' as it was before, but rather the opposites within the God-image itself (Jung, MDR:370-371).

\section{CONCLUSION}

The question as to whether evil is a human phenomenon or whether it has a metaphysical structure still hovers over a post-Christian and a post-Jungian world. Be that as it may, psychologically speaking Answer to $J o b$ can be experienced as a 'cup of suffering' being passed to the ordinary, mortal, modern man in which the 'bill of the Christian era is presented to us' (Jung , CW18:§1661). Christianity inherited Yahwistic contradictions personified in the metaphysical opposition between Christ and Satan (Dourley 2007:284). In this split Christ incarnated the good side of God and presumably delivered mankind from evil. However,

the dark God has slipped the atom bomb and chemical weapons into [man's] hands and given him the power to empty out the 
apocalyptic vials of wrath on his fellow creatures. Since he has been granted an almost godlike power, he can no longer remain blind and unconscious (Jung 1952, ATJ, CW11:§747).

These telling lines announce the new dispensation: mankind has become an essential component of the divine drama and is forced to become responsible for how the dark side of God manifests through the human nature. The battle of good and evil, the 'raging conflict of opposites' is to be fought within the soul of the individual (Jung, in Lammers 2007a:264265; Stein 2007:315). That is, to come to grips with evil more consciously means, not only, the acceptance that each person contains both darkness and light, but also, the self-knowledge of 'how much good we can do and what crimes we are capable of.' (MDR:362).

Today we are still, individually and collectively, striving to understand the pathological motivations for evil acts and the connection of violence with religion. Both history and the current political climate show that when evil breaks out, violence escalates, and what would be normally repressed becomes acceptable; and in the end countries go to war. What is more, the consequences and the aftermath of evil acts are just what they have always been: death of innocents, marginalised communities, millions of refugees with very little hope for realistic resolution.

Lying at the heart of Jung's Answer to Job was a pressing message, valid in his time and still valid today:

We have experienced things so unheard of and so staggering that the question of whether such things are in any way reconcilable with the idea of a good God has become burningly topical. It is no longer a problem for experts in theological seminaries, but a universal religious nightmare, to the solution of which even a layman in theology like myself can, or perhaps must, make a contribution (Jung 1952, ATJ, CW11:§736).

This concern brings the topic closer to contemporary research and debate about a new Anthropocene epoch. ${ }^{40}$ Simon L. Lewis (Professor of Global Change Science) and Mark A. Maslin (Professor of Earth Systems

${ }^{40}$ Combining the Greek words for 'human' and 'recent time', scientists have named this new period of time the Anthropocene. It describes when Homo sapiens became a geological superpower, setting Earth on a new path in its long development. The Anthropocene is a turning point in the history of humanity, the history of life, and the history of the Earth itself. It is a new chapter in the chronicle of life and a new chapter of the human story (Lewis and Maslin 2018:5). 
Science), both at University College London, have pointed out that the chemical signal from nuclear fallout is one of the many human impacts on the environment. In 2015, a new model was proposed which recognised the first demonstration of a nuclear weapon as marking the death of a previous epoch, the Holocene, and the beginning of a new one, the Anthropocene: 'the nuclear blast conducted on 16 July 1945 in the Jornada del Muerto desert, New Mexico, is the ground zero of the Anthropocene' (Lewis \& Maslin 2018:291). The scientific evidence that the power of human actions has created a new geological epoch, somehow confirms Jung's view that even the darkest shadow represents an aspect of every single one of us.

The Guild of Analytical Psychology, London punita.miranda@gmail.com

\section{REFERENCES}

Aquinas, Thomas. 1993. Selected Philosophical Writings. Selected and translated by Timothy McDermott. Oxford: Oxford University Press.

Aristotle. 1933. Metaphysics, Books I-IX. Loeb Classical Library, No. 271. Translated by Hugh Tredennick. Cambridge, Mass.: Harvard University Press.

Arraj, Tyra. 2015. 'Profiles in Jungian-Christian Dialogue with Adrian Cunningham'. Online Interview Transcript: http://www.innerexplorations .com/catjc/3.htm.

Augustine. 1912. Confessions, Books I-VIII. Loeb Classical Library, No. 26. Translated by William Watts. Cambridge, Mass.: Harvard University Press.

Bair, Deirdre. 2003. Jung, A Biography, Boston: Little Brown.

Bishop,Paul.2002.Jung 's AnswertoJob:ACommentary.London:Routledge.

Brooks, Robin. 2011. 'Un-thought out metaphysics in analytical psychology: a critique of Jung's epistemological basis for psychic reality'. Journal of Analytical Psychology 56:492-513.

Buber, Martin. 1952. Eclipse of God: Studies in the Relation between 
Religion and Philosophy. New York: Harper and Row.

Bulkeley, Kelly \& Clodagh Weldon (Eds). 2011. Teaching Jung. Oxford: Oxford University Press.

Chase, Steven. 2013. Job: A Theological Commentary on the Bible. Louisville: Westminster John Knox Press.

Corey, Lawrence. 1990. 'For the Sake of God: a Reply to Jung'. The San Francisco Jung Institute Library Journal, Vol. 9, No. 1:27-37.

Cunningham, Adrian. 1981. 'Victor White and C.G. Jung: The Fateful Encounter of the White Raven and the Gnostic'. New Blackfriars 62:320-334.

—. 2007. 'Victor White: a memoir', Appendix 5, in Lammers, Ann \& Adrian Cunningham (Eds). The Jung-White Letters. London: Routledge, 2007, pp. 307-36.

Davies, Brian (Ed). 2001. The 'De Malo' of Thomas Aquinas. Oxford: Oxford University Press.

Dourley, John. 2007. 'The Jung-White dialogue and why it couldn't work and won't go away'. Journal of Analytical Psychology 52:275-295.

- 2009. 'The Religious Significance of Jung's Psychology, The International Journal for the Psychology and Religion 5:2:73-89.

Drob, Sanford 2012. Reading the Red Book: An Interpretative Guide to C.G. Jung's Liber Novus, New Orleans: Spring Journal Books.

Edinger, Edward. 1992a. The Creation of Consciousness: Jung's Myth for Modern Man. Toronto: Inner City Books.

1992b. Transformation of the God-Image: An Elucidation of Jung's Answer to Job. Toronto: Inner City Books.

Evans, Erastus. 1954. 'An Assessment of Jung's Answer to Job', The Guild of Pastoral Psychology 78:5- 26.

Fordham, Michael. 1955. 'An Appreciation of Answer to Job', British Journal of Medical Psychology, 28:271-73.

Gilbert, Robert (Ed). 2008. Knowledge of the Heart: Gnostic Movements and Secret Traditions. Surrey: Lewis Masonic/Ian Allan Publishing.

Goethe, J. W. 2007. Faust, translated, with and introduction and notes by John R. Williams. London: Wordsworth Classic of World Literature.

Hannah, Barbara. 2001. Encounters with the Soul: Active Imagination 
as Developed by C.G Jung. Brooklyn NY: Chiron Publications.

Heisig, James. 1973. 'Jung and Theology: A Bibliographical Essay'. Spring, An Annual of Archetypal Psychology and Jungian Thought. 204-55. X

1979. Imago Dei: a Study of C. G. Jung's Psychology of Religion. Lewisburg: Bucknell University Press.

Hull, R.F.C. 1971. 'Bibliographical Notes on Active Imagination in the Works of C.G. Jung'. Spring, An Annual of Archetypal Psychology and Jungian Thought. 115-120.

Huskinson, Lucy (Ed). 2008. Dreaming the Myth Onwards: New Directions in Jungian Therapy and Thought. London: Routledge. Jaffé, Aniela. 1975. The Myth of Meaning. New York: Penguin Books. Jung, C. G. 1973. C. G. Jung Letters, selected and translated by Gerhard Adler in collaboration with Aniela Jaffé, translated by R.F.C. Hull, volumes 1 \& 2, 1906-1961. London: Routledge \& Kegan Paul. vol. 6 .

[1921]. Psychological Types. Collected Works of C. G. Jung, . [1951]. Aion: Researches of the Phenomenology of the Self. Collected Works of C. G. Jung, vol. 9ii.

- [1952]. Answer to Job. Collected Works of C. G. Jung, vol. 11, $\S \S 553-758$.

- [1952/1953]. 'Foreword to White's God and the Unconscious'. In Psychology and Religion: West and East. Collected Works of C. G. Jung, vol. 11, §§ 449- 467.

- [1953]. Two Essays on Analytical Psychology. Collected Works of C. G. Jung, vol. 7.

- [1953]. The Structure and Dynamics of the Psyche. Collected Works of C. G. Jung, vol. 8.

- [1954]. The Symbolic Life, Miscellaneous Writings. Collected Works of C. G. Jung, vol. 18.

- [1955/1956]. Mysterium Coniunctionis. Collected Works of C.

G. Jung, vol. 14.

. [1958]. Psychology and Religion: West and East. Collected Works of C. G. Jung, vol. 11. 
[1964]. Civilization in Transition. Collected Works of C. G. Jung. vol. 10.

-. [1964]. Man and His Symbols, London: Aldus Books Limited.

- [1968]. Alchemical Studies. Collected Works of C. G. Jung, vol. 13.

1989[1934/1939]. Nietzsche's Zarathustra: Notes of the Seminar Given in 1934-9, Vol. 2. Princeton, NJ: Princeton University Press.

- 2009. The Red Book: Liber Novus, edited and introduced by Sonu Shamdasani. London \& New York: W.W. Norton \& Company.

- 2010. Answer to Job, with a foreword by Sonu Shamdasani.

Princeton: Princeton University Press.

Jung, Carl Gustav / Jaffé, Aniela. 1995[1962/1983]. Memories, Dreams, Reflections. Tr. Richard and Clara Winston. London: Fontana Press.

Kille, Andrew D. 2001. Psychological Biblical Criticism. Minneapolis: Augsburg Fortress.

Kings, Steven. 1997. 'Jung's Hermeneutics of Scripture'. The Journal of Religion. Vol. 77, No. 2:233-251.

Lambert, Kenneth. 1955. Review: Jung's Answer to Job, Journal of Analytical Psychology, Vol. 1:1:100-108.

Lammers, Ann. 1994. In God's Shadow: The Collaboration of Victor White and C.G. Jung. Mahwah, NJ: Paulist Press.

- 2005. "“The Missing Fourth' in the Jung-White letters". Guild of Pastoral Psychology 287:1-24.

Lammers, Ann and Adrian Cunningham (Eds). 2007a. The Jung-White Letters. London: Routledge.

- 2007b. 'Jung and White and the God of Terrible Double Aspect'. Journal of Analytical Psychology 52:253-274.

Lévy-Valensi, Éliane. 1991. Job : réponse à Jung. Paris: Éditions du Cerf.

Lewis, Simon and Mark Maslin. 2018. The Human Planet: How we created the Anthropocene. London: Penguin Random House.

Livingston, James C. 1997. Modern Christian Thought, Vol. I. The Enlightenment and the Nineteenth Century. New Jersey: Prentice-Hall.

- 2000. Modern Christian Thought, Vol. II. The Twentieth Century. New Jersey: Prentice-Hall. 
MacKenna, Christopher. 2008. 'Jung's White Raven', Review: The JungWhite Letters. British Journal of Psychotherapy, Vol. 24, No. 3:365-379.

Maillard, Christine. 2011. 'La penseé de Carl Gustav Jung et les courants néo-gnostiques de la première moitié du XXème siècle'. In Christine Maillard (ed.). Arts, sciences et psychologie. L'élaboration de la pensée de Carl Gustav Jung entre 'Fin de siècle' et Première Guerre mondiale. Autour du Livre Rouge, Strasbourg: Recherches Germaniques 8: 99-116.

—. 2014. 'Jung's "Seven Sermons to the Dead" (1916), A Gnosis for Modernity: a Multicultural Vision of Spirituality', In: The Red Book: Reflections on C. G. Jung's Liber Novus, edited by Thomas Kirsch and George Hogenson, London: Routledge. 81-93.

- 2017. Au Cour du Livre Rouge: Les Sept Sermons aux Morts, Paris: La Compagnie du Livre Rouge.

McGuire, William \& R.F.C. Hull (Eds). 1977. C.G. Jung Speaking: Interviews and Encounters. Princeton: Princeton University Press, Bollingen Series.

Meyer, Werner. 2008. 'Birthpangs of a Christianity for the Future?' Review: The Jung-White Letters. Jung Journal: Culture \& Psyche, Vol.2, No.4:95-97.

Miller, David Leroy. 1995. Jung and the interpretation of the Bible. New York: Continuum

Nagy, Marilyn. 1991. Philosophical Issues in the Psychology of C.G. Jung. New York: State of University Press.

Naso, Ronald and Jon Mills. 2016. Ethics of Evil: Psychoanalytic Investigations. London and New York: Routledge.

- 2016. Humanizing Evil: Psychoanalytic, Philosophical and Clinical Perspectives. London and New York: Routledge.

Oglesby, Les. 2017. C. G. Jung and Hans Urs von Balthasar: God and Evil - A Critical Comparison. Hove: Routledge.

Owens, Lance S. 2010. 'The Hermeneutics of Vision: C.G. Jung and Liber Novus', The Gnostic: A Journal of Gnosticism, Western Esotericism and Spirituality 3: 23-36.

Parsons, Gregory. 1981. 'The Structure and Purpose of the Book of Job'. Biblioteca Sacra, 138:550:139-57. 1981. 'Literary Features of the Book of Job'. Biblioteca Sacra, 
$138: 551: 213-29$.

Ribi, Alfred. 2013. The Search for Roots: C.G. Jung and the Tradition of Gnosis. Los Angeles: Gnosis Archive Books.

Rollins, Wayne G. 1983. Jung and the Bible. Louisville, KY: Westminster John Knox Press

- 1999. Soul and psyche: The Bible in psychological perspective. Minneapolis: Augsburg Fortress.

Rutte, Joseph. 2009. 'The White-Jung Friendship: The Untold Story', Psychological Perspectives 52:292-314.

Schlamm, Leon. 2004. Review: Jung's Answer to Job: A Commentary. Harvest: Journal of Jungian Studies, 50:2:181-195.

- 2008a. 'Active Imagination in Answer to Job' in Lucy Huskinson (Ed). Dreaming the Myth Onwards: New Directions in Jungian Therapy and Thought. London: Routledge. 109-121.

Sedgwick, David. 2002. 'Answer to Job Revisited: Jung on the Problem of Evil'.TheSanFranciscoJungInstituteLibraryJournal.Vol.21,No.3:5-22.

Shamdasani, Sonu. 1995. 'Memories, Dreams, Omissions'. Spring: A Journal of Archetype and Culture 57:111-132.

- 2010. 'Foreword' in Jung, Answer to Job. Princeton: Princeton University Press. vii-x.

- 2009. Introduction in: The Red Book: Liber Novus. London \& New York: W.W. Norton \& Company.

- 2012. C. G. Jung: A Biography in Books. New York, NY: W.W. Norton \& Company.

Spiegelman, Marvin. 2006. 'C. G. Jung's Answer to Job: A Half Century Later'. Journal of Jungian Theory and Practice 8:1:1-17.

Stein, Murray. 1995. Jung on Evil. Hove: Routledge. - 2003. 'The Role of Victor White in C. G. Jung's Writings'. Oxford: Guild of Pastoral Psychology 285:1-24.

- 2007a. 'Of texts and contexts: reflections upon the publication of The Jung-White Letters', Journal of Analytical Psychology 52:297-319.

—. 2007b. 'Foreword' in Lammers, Ann and Adrian Cunningham (Eds). The Jung-White Letters. London: Routledge. ix-xi. 
Stein, Murray \& Raya Jones (Eds). 2010. Cultures and Identities in Transition. London: Routledge.

- 2011. Review: 'Fr. Victor White OP.: The Story of Jung's "White Raven", The Catholic Historical Review 97:3:601-602.

Tardieu, Michel. 2009. Manichaeism. Illinois: University of Illinois Press.

Von Franz, Marie-Louise. 1995. Shadow and Evil in Fairy Tales. Boston: Shambhala.

- 1997. Psychotherapy. Boston: Shambhala.

. 1998. C.G. Jung: His Myth in Our Time. Toronto: Inner City Books.

Weldon, Clodagh. 2007. Fr. Victor White OP.: The Story of Jung's 'White Raven'. Scranton, PA: University of Scranton Press.

. 2010. 'Types of Thomists: Victor White's use of Aquinas exemplary of a dialectical synthesis', in Stein, Murray \& Raya Jones (Eds). Cultures and Identities in Transition. London: Routledge. 175-182. 2011. 'God on the Couch', in Bulkeley, Kelly \& Weldon, Clodagh(Eds).TeachingJung. Oxford:OxfordUniversityPress. 115-125.

White, Victor. 1949. 'Eranos: 1947/1948', Dominican Studies, 4 (1949), pp. 395-400.

1952. God and the Unconscious. London: Harvill Press. 1960. Soul and Psyche: An Enquiry into the Relationship of Psychotherapy and Religion. New York: Harper.

. 2007. 'Jung on Job', Appendix 6, in Lammers, Ann and Adrian Cunningham(Eds). TheJung-WhiteLetters.London:Routledge.349-356. 